Вісник Житомирсъкого державного иніверситети імені Івана Франка. Педагогічні науки. Bun. 4 (103)

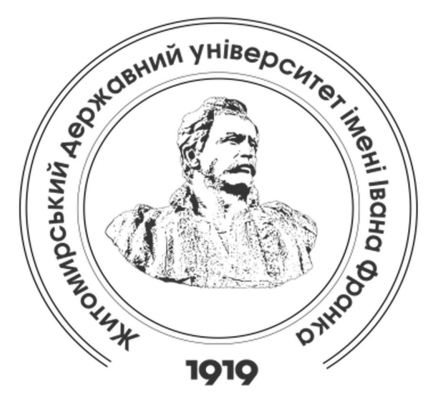

Zhytomyr Ivan Franko State University Journal. Pedagogical Sciences. Vol. 4 (103)

Вісник Житомирського державного університету імені Івана Франка. Педагогічні науки. Вип. 4 (103)

ISSN (Online): 2664-0155

UDC 378:37.013.75:811.111

DOI 10.35433/pedagogy.4(103).2020.109-117

\title{
THE CHARACTERISTICS OF WEBQUESTS PROMOTING ENGLISH- LANGUAGE TEACHER TRAINING FOR INCLUSIVE INSTRUCTION OF LEARNERS WITH DISABILITY
}

\section{N. S. Shcherba*}

Inclusion in Ukraine has been the national educational policy since 2018. Most of postgraduate educational institutions that provide professional development opportunities, responded to the need for preparing in-service teachers for addressing inclusion-related challenges. Relevant academic modules and courses have been designed and are being delivered all over the country. In the same time, a survey conducted among 136 teachers of English-as-a-foreign-language (EFL) revealed that its results are insufficient for effective teaching. It may be caused by three factors. The first one is the lack of trainers' knowledge, skills and experience of teaching learners with disabilities that influences the quality of professional development. The second one is the segregation mentality that can still be found in educationalists and which explains their unwillingness to accept inclusion of learners with disability. The last reason is the complex nature of a typical professional development course that highlights numerous issues related to language teaching and leaves little time for reflection and practice. Thus, the theoretical input provided cannot result in readiness for inclusion.

The present research is aimed at studying the potential of WebQuests as means of EFL teacher training for inclusive instruction of learners with disability. The study has shown that WQs promote the development of teachers' low-order and high-order thinking skills irrespectively of their level (shorter-term or longer-term). Besides, such WQ characteristics as: their practical orientation, holistic, pro-inclusive, comprehensive, proactive and subject-specific nature provide effective preparation for inclusive instruction of learners with disability. Among other benefits of WebQuests is the simplicity of their dissemination among would-be and working EFL teachers.

Key words: WebQuest, a teacher of English-as-a-foreign-language, pre-service teachers, teacher training, special educational needs, a learner with disability.

\footnotetext{
${ }^{*}$ Candidate of Pedagogical Sciences (PhD in Pedagogy), Docent

(Zhytomyr State Ivan Franko University)

scherbanatasha@gmail.com

ORCID: 0000-0002-5467-4292
} 


\title{
ХАРАКТЕРИСТИКИ ВЕБ-КВЕСТІВ, ЩО СПРИЯЮТЬ ПІДГОТОВЦІ

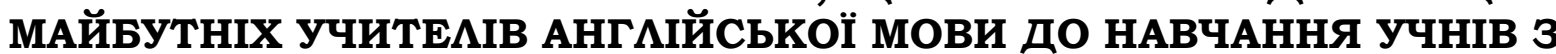 ІНВАМІДНІСТЮ
}

\author{
Н. С. Щерба
}

Інклюзія в Україні є наиіональною освітньою політикою з 2018 року. У відповідъ на необхінність підготовки вчителів до подолання трудноиів інклюзивного навчання, більшість вишів та післядипломних освітніх закладів пропонують сьогодні можливості для підвищення їх кваліфікаиії. Відповідні освітні модулі та курси розробляються та запроваджуються по всій країні. Водночас, як показало опитування, проведене серед 136 учителів англійської мови, результати такої підготовки $є$ недостатніми для ефективного викладання. Причинами иього можуть слугувати три фрактори. По-перие, в учителів бракує базових знань, умінь і досвіду навчання учнів з інвалідністю, шо впливає на загальний рівень їх готовності до інклюзивного навчання. По-друге, ізоляиійні моделі інвалідності все ше характерні для деяких освітян, шо негативно впливає на їх бажання та готовність до прийняття інклюзивного навчання учнів з інвалідністю. Нарешті, третьою причиною є комплексна структура типового курсу підвишення кваліфікаиї, ијо висвітлюе численні питання, пов'язані з лінгвістикою та методикою навчання іноземної мови, має інтенсивний характер і не передбачає тривалої практики.

Дане дослідження наиілене на вивчення потениіалу веб-квестів як засобів підготовки майбутніх учителів іноземної мови до інклюзивного навчання учнів з інвалідністю. Як було виявлено, веб-квести сприяють розвитку розумових умінь нижчого та вишого порядку учителів незалежно віо своєї тривалості (рівня). Крім того, такі характеристики вебквестів, як: практична зорієнтованість, а також їх холістична, про-інклюзивна, комплексна, про-активна та предметна природа забезпечують ефективність підготовки майбутніх учителів до інклюзивного навчання учнів з інвалідністю. Серед інших переваг веб-квестів - простота їх розповсюдження серед майбутніх $i$ праиюючих учителів іноземних мов.

Ключові слова: веб-квест, вчитель аналійсъкої мови як іноземної, майбутні вчителі, професійно-педагогічна підготовка, особливі освітні потреби, учень з інвалідністю.

Introduction of the issue. The
necessity of preparing pre-service
teachers for inclusive instruction of
children and youth with special
educational needs is stated in the
Salamanka Declaration [11]. Especially
crucial is such teacher-training for
learners with disability whose special
educational needs are diverse and
sometimes not easy to cater to.
Numerous researchers (Alawadh, 2016;
Avramidis \& Norwich, 2002; Giangreco
et al., 1993; Haq and Mundia, 2012;
Hay, Smit and Paulsen, 2001; Kirillova
and Faizrakhmanova, 2016; Leyser and
Abrams, 1982; Ross-Hill, 2009; Taylor,
Ahlgrim-Delzell and Flowers, 2010 and
others) believe that the development of
educationalists' ability to cope with
challenging inclusive classroom
situations is promoted by relevant

customized knowledge, skills and experience. In the same time, the lack of appropriate training contributes to the dissemination of isolation disability models in the society which results in numerous negative consequences (like segregation of children with disability, bullying, and other forms of discrimination).

Since 2016, 14 Ukrainian universities, that participate in "New Generation School Teachers" project, have been providing their fourth-year students with an academic module called "Catering for Special Educational Needs" [10]. It is a part of a crosscutting training course entitled "The Methodology of Teaching English as a Foreign Language". The project was launched by the Ministry of Education and Science of Ukraine and the British 
Council. The module materials cover all the key concepts and vital topics of inclusive instruction, but its content is outlined as theoretical rather than a set of hands-on activities. To make it more practice-oriented and problem-solving, academics need to have relevant expertise of inclusive teaching at school. But no relevant mechanisms are devised, so "the blind are still leading the blind". There is another option of teacher-training for inclusive classroom.

Several higher educational institutions (such as Zhytomyr State Ivan Franko University, Khmel'nyts'kyi National Pedagogical Hryhoriy Savych Skovoroda University, Uman State Pedagogical Pavlo Tychyna University, Rivne State Humanitarian University and some others) support fundamental researches dedicated to preparing preservice or in-service teachers for inclusive instruction. A number of short-term academic courses have been designed to share the relevant findings with students. But these are only available for those enrolled in correspondent programs of these institutions. Besides, there are no mechanisms for spreading such findings. In this situation the research into blended and virtual learning tools might become a viable solution to the issue described. These classroom formats might help disseminate highquality courses and add educational value to the existing ones.

Nowadays, traditional classroom instruction is considered the foundational method of teacher training in Ukraine. A typical academic course employs a succession of face-to-face lectures and practical sessions followed by a credit or an exam. In the same time, the number of academics using supplemental virtual learning tools in their professional activities has been constantly increasing in the last decades. Besides, the COVID-19 pandemic encouraged educationalists to experiment with diverse virtual learning tools, like: videoconferencing, virtual classrooms, WebQuests (WQ), social networking etc. The author of this article, likewise, had an opportunity to try out conventional, blended and virtual classroom formats while delivering a course "Foreign Language Instruction of Children with Special Educational Needs" to master degree program students of day and extramural department in Zhytomyr Ivan Franko State University. This article is dedicated to the analysis of challenges and educational potential of using WQs as means of preparing would-be English teachers for inclusive instruction of children with disability.

Current state of the issue. WebQuest as a method and a means of teaching was originated by Dr. Bernie Dodge, Tom March, the San Diego Unified School District's Educational Technology staff and participants from the Teach the Teachers Consortium [1; 6; 9]. Dodge [1] defined it as "an inquiryoriented activity in which some or all of the information that learners interact with comes from resources on the internet, optionally supplemented with videoconferencing". According to Dodge, its possible outcomes depend on a WQ level that may be short- or long-term. Short-term WQs take 1-3 class sessions and long-term ones take between one week and a month [1]. The author believes that shorter term WQs are aimed at knowledge acquisition and integration. Their possible outcomes are awareness and understanding of a significant amount of new information. Longer term WQs are aimed at "extending and refining knowledge". Their results are: ability to analyze a body of knowledge, transform and apply it for creating an on-line or off-line product [2]. According to GodwinJones, by completing long-term WQs learners may produce documents that collect, summarize, and synthesize the information gathered. Their genres may range from a report, presentation, questionnaire to a website [5]. 
Dudeney, whose point we support, argues that WQs do not only improve low order thinking skills (LOTS) but they also encourage critical (or higher order) ones (HOTS), including: comparing, classifying, inducing, deducing, analyzing errors, constructing support, abstraction, analyzing perspectives, etc. irrespectively of their level [4: 123]. Marzano supplies an extended list of HOTS that includes: 1) Comparing (identifying and articulating similarities and differences between things). 2) Classifying (grouping things into definable categories on the basis of their attributes). 3) Inducing (inferring unknown generalizations or principles from observations or analysis). 4) Deducing (inferring unstated consequences and conditions from given principles and generalizations). 5) Analyzing errors (identifying and articulating errors in one's own or others' thinking). 6) Constructing support (constructing a system of support or proof for an assertion). 7) Abstraction (identifying and articulating the underlying theme or general pattern of information). 8) Analyzing perspectives (identifying and articulating personal perspectives about issues) [7].

In other words, WQs of any level that provide activities listed above promote the development of both - LOTS and HOTS [4; 7].

The outline of unresolved issues brought up in the article. Aiming to implement WebQuests into pre-service English teacher training, it is crucial to find an answer to the research question that has not been resolved in scientific literature: What WebQuest characteristics can promote the subsequent development of teachers' knowledge, skills and experience necessary for teaching learners with disability?

Aim of research is to select and substantiate WQ characteristics that would make them compatible with the aims of preparing would-be English teacher for inclusive instruction.

Results and discussion. To single out the prerequisites of designing WQ aimed at preparing would-be English teachers for inclusive instruction, it is important to realize both - the current state of teachers' knowledge, skills and experience, and the desired results of their preparation by means of WQ application. Thus, in 2018-2019 and in 2019-2020 two survey sessions were conducted among 45 and 91 Englishas-a-foreign-language (EFL) teachers enrolled in post-graduate professional development courses in Zhytomyr. It included 3 questions:

1. Do you have any experience of teaching children with disabilities? (The relevant categories were listed below).

2. Knowledge of teaching English to learners with disability of what categories do you lack?

3. Do you think that you have sufficient skills for teaching children with disabilities? (The relevant categories were listed further).

As the survey results showed, a substantial part of the teachers had neither sufficient knowledge nor proper skills or experience. Figure 1 illustrates relevant self-assessment indices of teachers' experience.

As it is confirmed by Fig. 1, the teachers in both groups had no experience of teaching learners with blindness and deafness. It is explained by the fact that practically all of these children study in special schools. The highest experience index was revealed in teaching learners with moderate speech disorders (33\%) as they traditionally study in mainstream schools. A need to learn more about such impairments was singled out by EFL teachers as important in the questionnaires. The same index (33\%) was revealed in the first group concerning teaching students with global developmental delay. According to Figure 1 no index in both groups exceeded 50\%. Thus, teachers' 
experience may be assessed as highly insufficient.

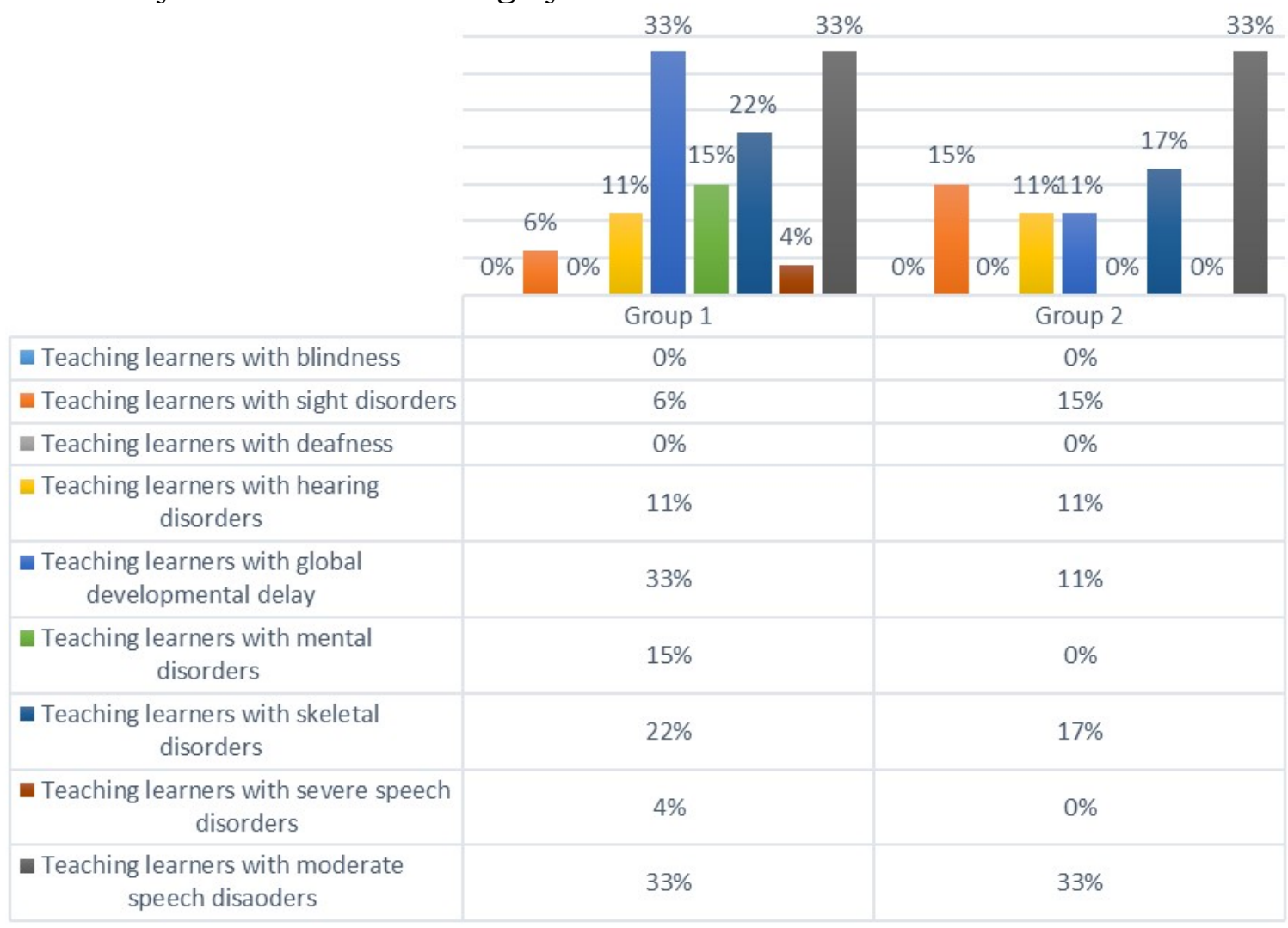

Fig. 1. EFL teachers' self-assessment of the experience concerning teaching learners with disability

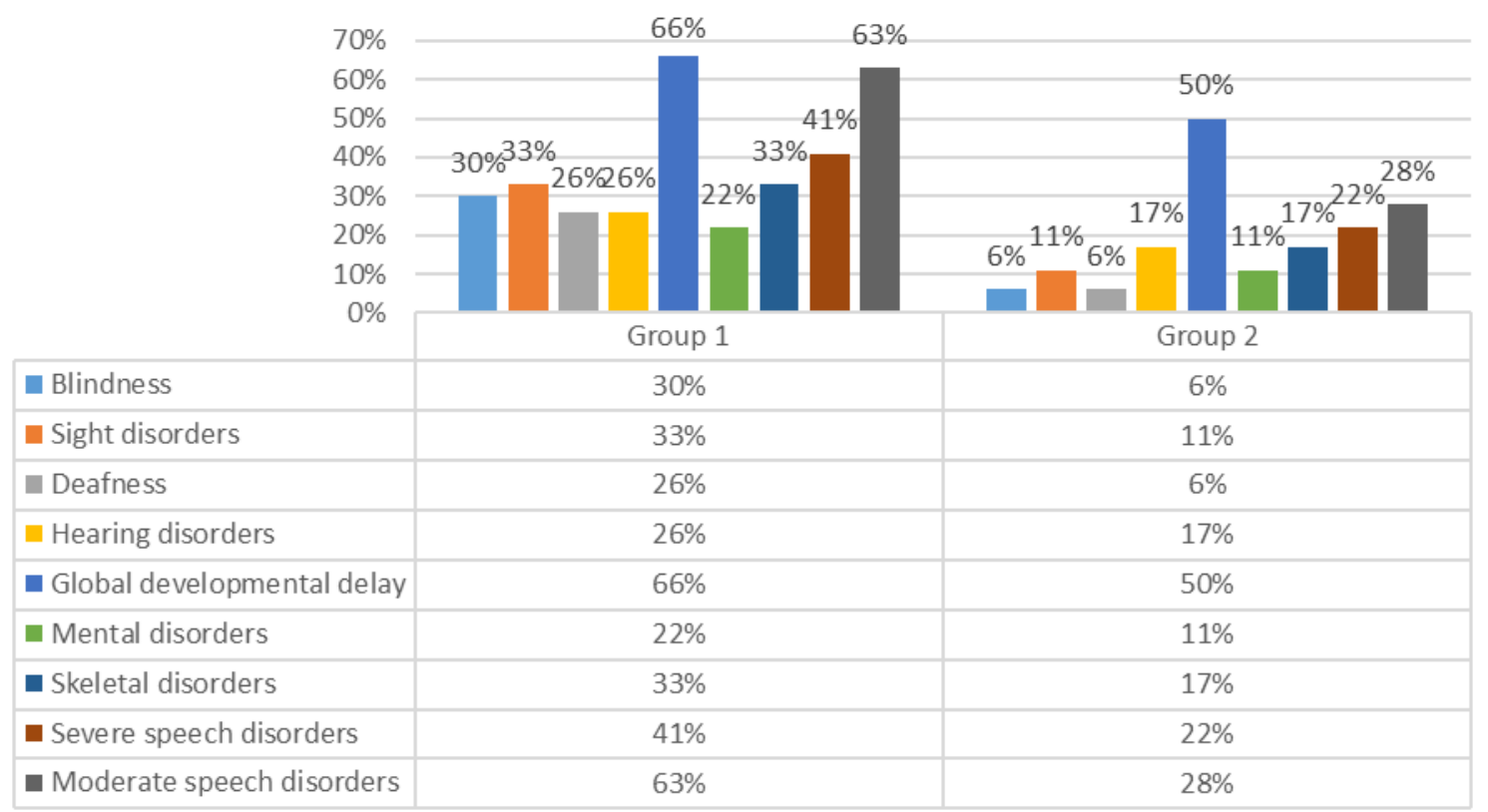

Fig. 2. Self-assessment of the need for acquiring additional knowledge of teaching different categories of learners with disability 
Fig. 2 reveals both: teachers' need to learn more about the peculiarities of work with different categories of learners with disability and the relevant professional interests. As it can be observed, the most intense interest was shown in the contexts of teaching learners with developmental delay $(66 \%$ and $50 \%$ ), and learners with moderate $(63 \%$ and $28 \%)$ and severe speech disorders $(41 \%$ and $22 \%$ respectively). The first index is explained by the fact that children with developmental delay

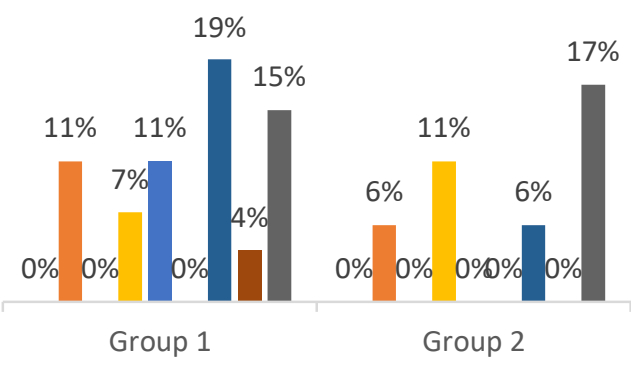

$\begin{array}{ll}\square \text { Teaching learners with blindness } & \square \text { Teaching learners with sight disorders } \\ \square \text { Teaching learners with deafness } & \text { Teaching learners with hearing disorders } \\ \square \text { Teaching learners with global developmental delay } & \square \text { Teaching learners with mental disorders } \\ \square \text { Teaching learners with skeletal disorders } & \text { Teaching learners with severe speech disorders } \\ \square \text { Teaching learners with moderate speech disorders } & \end{array}$

Fig. 3. EFL teachers' skills of inclusive teaching learners with disability

As it was found out, EFL teachers assess relevant skills as highly insufficient. None of them can teach learners with deafness, blindness and cognitive challenges. Only $4 \%$ in group 1 can teach children with severe speech disorders (with $0 \%$ index in group 2), only $11 \%$ in group 1 can teach learners with global developmental delay (with $0 \%$ index in group 2), and only $4 \%$ in group 1 claim to be able to teach learners with severe speech disorders (with $0 \%$ index in group 2). In the same time, the highest index in both groups refers to teaching learners with moderate speech disorders $(15 \%$ and are supposed to be enrolled into mainstream schools and they are often not exempted from language learning. As for the 2nd and the 3rd ones, teachers' awareness of the ways of reducing their effects is crucial for teaching English pronunciation and speaking.

Finally, Fig. 3 illustrates selfassessment of skills of teaching learners with disability. 


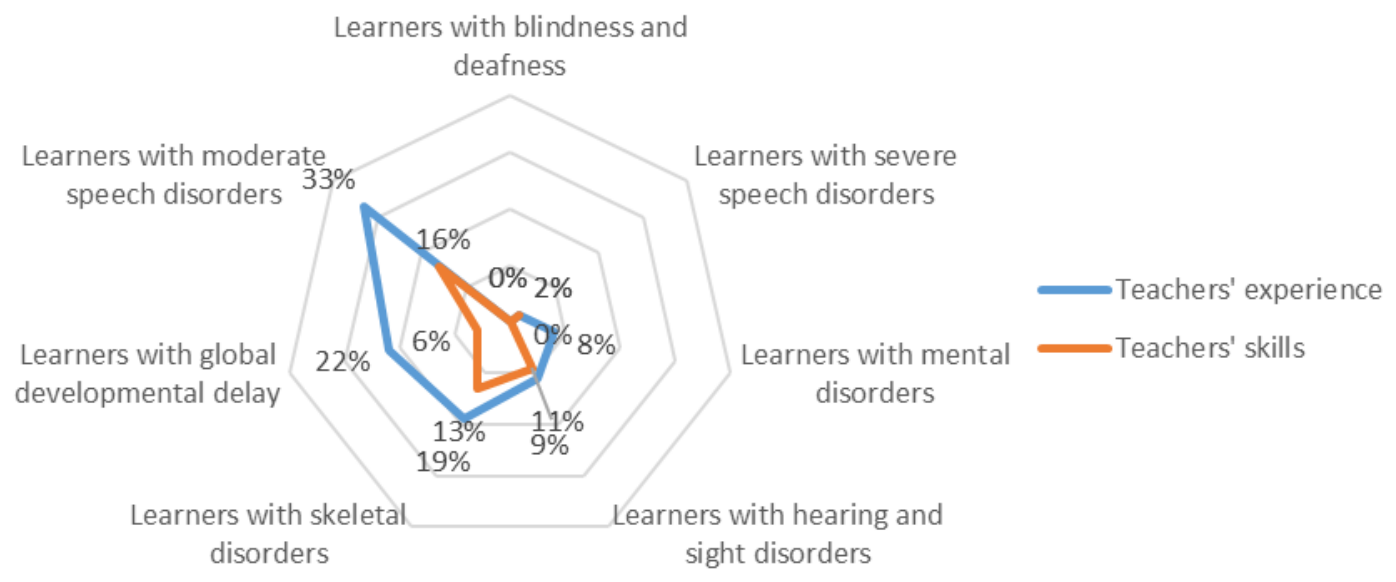

Fig. 4. EFL teachers' self-assessed experience and skills of teaching different categories of learners with disability (arithmetic mean indices of both groups)

By comparing the indices of questionnaire completion, a number of conclusions may be drawn. Firstly, teachers revealed professional interest in all categories of disability, and especially of: developmental delay and speech-sound disorders which should be taken into consideration while designing WebQuests. Secondly, the indices of skills and experience acquired by EFL teachers do not exceed $33 \%$. This means that they are generally not prepared for work with learners with disability in mainstream school setting. As 2 subsequent research sessions confirm, the situation does not change spontaneously. Thus, WQs should be designed in a way that would enable would-be teachers to develop skills and gain initial experience. Thirdly, WQs aimed at preparing EFL teachers for educating learners with disability should be practice-oriented (e.g. modeling and analyzing professional activities) as the lowest position in the research results was taken by the skills indices.

The conclusions mentioned above allowed us to select characteristics of WQs aimed at preparing would-be teachers for inclusive instruction. Such WQs should be:
- $\quad$ practice-oriented - involving inquiry into the methods, systems, programs, and policies related to teaching learners with disability and including investigation of particular examples and cases [8];

- holistic - encompassing the development of both - lower and higher order thinking skills (LOTS and HOTS) as a result of trainee's inquiry and subsequent problems-solving activities;

- pro-inclusive - aimed at overcoming teachers' segregation mentality;

- comprehensive - providing EFL teachers with sufficient scientific information and presented as a course covering all vital issues of inclusion and disability;

- proactive - providing tools and procedures of addressing inclusionrelated problems and concerns that may emerge in the classroom;

- subject-specific - concerning the peculiarities of teaching EFL.

Proceeding from the summary of theoretical research, the survey results and the characteristics presented above, four WQs were designed on zunal.com web-platform [12-15]. These can illustrate the characteristics laid out above. All the WQs are Design 
Tasks (requiring learners "to create a product or plan of action that accomplishes a pre-determined goal and works within specified constraints" [3] or a combination of tasks including a Design one. All of them are shortterm and comprise a case to be solved by creating a plan of actions in a challenging classroom situation and considering accompanying constraints. The topics of WQs were chosen according to teachers' professional needs outlined in the survey above.

\section{Conclusions and research} perspectives. Teaching learners with disability is a challenge for general educators irrespectively of a country. Teachers are obliged to provide instruction for learners with disability by educational legislation but they may deny inclusion philosophies by their actions and attitude. They can refuse to contribute additional effort and time into these children due to the lack of the relevant knowledge, skills, experience or other reasons (e.g. financial). But teachers' rejection of children with disability leads to a hidden form of segregation inside a classroom.

Most researches worldwide confirm that it is not only knowledge, skills and experience that cause teachers' acceptance of children with disability. For instance, the sociocultural dimension of preparing would-be English teachers for inclusion is its another important and underestimated factor that is also underresearched. That is why, it is expedient to proceed experimenting with relevant methods, forms and means of teacher-training (including the ICTs) to promote the necessary level of preparing (would-be) EFL teachers for teaching learners with disabilities.

\section{REFERENCES}

1. Dodge, B. (1997). Some thoughts about WebQuests. webquest.org. Retrieved from http: //webquest.org/sdsu/about_webq uests.html [in English].

2. Dodge, B. (1998). WebQuest: a strategy for scaffolding higher-level learning. Presented at the national educational computing conference, San Diego, June 22-24, 1998. webquest.sdsu.edu. Retrieved from http://webquest.sdsu.edu/necc98.htm [in English].

3. Dodge, B. (2002). WebQuest taskonomy: a taxonomy of tasks. webquest.org. Retrieved from http://webquest.org/sdsu/taskonomy. html [in English].

4. Dudeney, G. (2007). The Internet and the language classroom: a practical guide for teachers (Cambridge handbooks for language teachers). 2nd edition. Cambridge University Press, 182 [in English].

5. Godwin-Jones, R. (2004). Language in action: from WebQuests to virtual realities. Language Learning \& Technology, 8(3), 9-14 [in English].

6. March, T. (1998). Why WebQuests? An introduction. Retrieved from

https://web.archive.org/web/2005021 4085350/https:/www.ozline.com/webq uests/intro.html [in English].

7. Marzano, R.J. (1992). A different kind of classroom: teaching with dimensions of learning. Alexandria Ya: Association for supervision and curriculum development [in English].

8. Mills, A.J., Durepos,G., \& Wiebe, E. (2012). Encyclopedia of case study research. methods.sagepub.com. Retrieved from https://methods.sagepub.com/Referen ce/encyc-of-case-study-research [in English].

9. Pinantoan, A. (2013). Webquests an introductory guide and resources. www.opencolleges.edu.au. Retrieved from

https://www.opencolleges.edu.au/infor med/teacher-resources/webquests / [in English].

10. New Generation School Teachers. (2016). www.britishcouncil.org.ua. 
Retrieved

from

http: / /www.britishcouncil.org.ua/en/t

each/projects/presett [in English].

11. The Salamanca Statement and Framework for Action on Special Needs Education. (1994). World Conferenceon Special Needs Education: Access and Quality. Salamanca, Spain, 7-10 June 1994, 22 [in English].

12. Shcherba, N.S. (2020a). The peculiarities of teaching speaking EFL / ESL learners with speech-sound disorders. zunal.com. Retrieved from http: / / zunal.com/webquest.php?w $=43$ 3008 [in English].

13. Shcherba, N.S. (2020b). The peculiarities of teaching hard of hearing
EFL / ESL learners in inclusive setting. zunal.com. Retrieved from www.zunal.com//webquest.php?w=433 174 [in English].

14. Shcherba, N. S. (2020c). The peculiarities of teaching EFL / ESL learners with vision impairments. zunal.com. Retrieved from www.zunal.com/ / webquest.php?w=435 230 [in English].

15. Shcherba, N. S. (2020d). The peculiarities of teaching EFL / ESL learners with autism spectrum disorder. zunal.com. zunal.com. Retrieved from www.zunal.com/ / webquest.php?w $=444$ 206 [in English].

Received: October 30, 2020 Accepted: December 10, 2020 